\title{
The Weeping King of Muslim Pietistic Tradition
}

\author{
David in the Kitāb al-wara' of 'Abd al-Malik b. Habīb (d. 238/853) \\ and in Earlier Islamic Sources
}

\author{
Mateusz Wilk
}

Kitāb al-wara' (Book of Religious Scrupulosity) by 'Abd al-Malik b. Habīb (d. 238/853) belongs to a tradition of third/ninth-century hadit compilations that deal with themes of piety and zuhd (lit. "mild asceticism" or "renunciation"). ${ }^{1}$ The surviving compilations on warac, a term usually translated as "religious scrupulosity," were authored by or ascribed to Ibn Hanbal (d. 242/855), al-Muhāsibī (d. 243/857), Ibn Abī al-Dunyā (d. 281/894),, ${ }^{2}$ and 'Abd al-Malik b. Habīb (d. 238/853). To this list we may add Kitāb al-zuhd wa-'l-ibāada wa-'l-wara' (The Book of Renunciation, Worship and Religious Scrupulosity) written by Asad b. Mūsā (d. 212/827), but the state in which this work has been preserved sets it apart from other similar compilations, as only traditions on Hell have survived from the book that must have originally included hadit on other topics as well. ${ }^{3}$

'Abd al-Malik b. Habīb was one of the principal figures in the early Malikism of al-Andalus. A full description of his life goes beyond the scope of the present work. Suffice it to say that he initially adhered to the madhab of al-Awzāi (which was, supposedly, the most popular legal school in al-Andalus before

1 For the term "mild asceticism" see Hurvitz, "Biographies and Mild Asceticism." Other important articles concerning models of piety in the hadit compilations of the time include Kinberg, "What Is Meant by Zuhd" and Melchert, "The Piety of the Hadith Folk." The present article is a result of my research on religious scrupulosity in third/ninth-century Islam, funded by the National Science Centre (NCN; grant Sonata 3; no. 2012/05/D/HS3/03521).

2 Although multiple editions of Ibn Hanbal's Kitäb al-wara' exist, I used mainly the one prepared by Zaynab Ibrāhīm al-Qarūṭ (published by Dār al-kutub al-ilmiyya, Beirut 1987). See also a German translation of this work by Pitschke, Skrupulöse Frömmigkeit im Frühen Islam. For similar works, see also al-Muhāsibī, Kitāb al-makāsib wa-'l-wara'; Ibn Abī al-Dunyā, Kitāb al-wara. I am currently preparing a critical edition and English translation of 'Abd al-Malik b. Habīb's Kitāb al-warac (University of Córdoba Press, forthcoming). The excerpts quoted in this paper are taken from this edition (with slight modifications when necessary).

3 See Asad b. Mūsā, Kitāb al-zuhd (Book of Renunciation). 
the advent of Malikism in the mid-third/ninth century), being a student of, among others, Șașaáa b. Sallām (d. 192/807 or 201/817) - a prominent Awzāite jurist - as well as of two important Proto-Maliki scholars, al-Ġāzī b. Qays (d. 199/815) and Ziyād b. Abī 'Abd al-Raḥmān, known as Šabțūn (d. 204/819-82o). ${ }^{4}$ Ibn Habib undertook a three-year voyage to the East, departing in 208/823824, during which he studied figh in Egypt (with, among others, Așbag b. al-Farağ [d. 224-225/839-840]) and in Medina (with famous Maliki masters like Muṭarrif [d. 220/835] and Ibn al-Mağišūn [d. 212/827]). Upon his return to his hometown, Elvira, he was summoned to the court of the Umayyad emir of al-Andalus, 'Abd al-Raḥmān II in 218/833. From this time onwards, he fulfilled the post of a "counselor jurist" (Ar. al-faqih al-mušāwar), which means that he was a member of the council of high-ranking jurists directly advising the emir. Ibn Habiib had retained this high position at the Cordoban court for twenty years, until his death in $238 / 853$. Throughout this period, he enjoyed considerable authority in the early Maliki circles of al-Andalus, often advising in high-profile judicial cases at the court. The most famous and controversial among them was the one of "the nephew of 'Ağab,"5 when Ibn Habib managed to oppose the majority vote of other jurists and cause the nephew of 'Ağab to be condemned to death. ${ }^{6}$

Many extant works are authored by or attributed to Abd al-Malik b. Habīb ${ }^{7}$ and it can safely be said that they constitute most of the Andalusi sources from the third/ninth century in our possession. In the present paper, I would like to focus on the (hitherto unpublished) Kitāb al-wara' in order to explore the image of King David that emerges from this source.

Kitāb al-wara' or Book of Religious Scrupulosity by 'Abd al-Malik b. Habīb has been preserved in the Arabic manuscript no. 5146 of the Biblioteca Nacional in Madrid (folios 18ov-201v). It forms a part of a florilegium, a collection of works on various topics. The manuscript certainly dates to a much later period than the text itself; the folios containing the treatise are written in a clear magribi

4 On the concept of "Proto-Malikis," being essentially the first generation of scholars who imported the Maliki doctrine to al-Andalus, see Fierro, "Proto-Malikis, Malikis and Reformed Malikis," 61-70.

5 'Ağab was the favorite concubine of the late emir al-Hakam I, the father of 'Abd alRahmān II.

6 For the most detailed discussion of this famous case, see Fierro, La heterodoxia en al-Andalus, 57-63. For detailed reconstructions of Ibn Habīb's life, see Arcas Campoy, Serrano Niza, "Ibn Habīb" and Arcas Campoy, "La autoridad doctrinal de 'Abd al-Malik ibn Habīb."

7 The published ones are Kitāb adab al-nisă’ (Book of Good Conduct of Women), Kitāa wașf al-firdaws (Book of Description of Paradise), Kitāb al-ta'rīh (Book of Chronology), Muhtașar fi-'l-țibb (Compendium of Medicine), Kitāb al-wādiḥa (The Clear Book), Ašrāt al-sā'a (Conditions of the Last Hour), Kitāb al-ribā (Book of Usury). 
script that may date to the fifteenth, sixteenth or even seventeenth century (no precise dating seems possible on the sole basis of paleography). ${ }^{8}$

As most similar compilations on religious scrupulosity (Ar. wara) and mild, renunciant asceticism (Ar. zuhd), Kitāb al-wara' of 'Abd al-Malik b. Habīb contains hadìt dealing with various problems of piety in social life. The discussion of the problem of distinction between zuhd and wara' exceeds the scope of the present study, yet it may be observed that zuhd often involves the idea of a positive act for the sake of God and Islam (e.g., renouncing luxuries, or sharing with the poor), while wara 'is more "negative," involving rigorous avoidance of things that can cause a pious man to cross the ever-elusive boundary between the licit (Ar. haläl) and the illicit (Ar. harām). It is then, in the first place, the avoidance of every doubt in religion and the religious way of life, including situations in which such doubts may arise. In Ibn Ḥabīb's compilation, we find the following tradition:

It is narrated from 'Abd al-Rahmān b. Habīb, from his father that the Messenger of God (on whom be peace and prayers) said: "Virtue is a trait of kindness and sin is what rankles in your breast, something that you would not like people to know about."

And Abū al-Dardā' used to say: "Good is in tranquility, and evil is in doubt, so leave what makes you doubtful for what does not."

From this and several other similar traditions contained in Kitāb al-warac, it transpires that scrupulosity is, at least to some extent, the avoidance of emotional anxiety caused by the danger of going astray and committing (even inadvertently) an illicit act. This is why one of the most common problems present in compilations on religious scrupulosity is finding licit means of sustenance, namely those that would allow a pious man to earn his living in a lawful way and become economically independent from others, being thereby able to fulfill his religious duties (offering alms from illicit gain is null and void; the obligation is considered unfulfilled under such circumstances). This is well exemplified by the following tradition quoted by Ibn Ḥabīb:

8 The folio numbers in the quoted texts refer to this manuscript.

9 See Ibn Habīb, Kitāb al-wara', no. 99, fol. 186v. 
Al-Hasan said: "The Messenger of God (on whom be peace and prayers) said: 'By the One in whose hand my soul is! It is better for you to take a rope, go to the woods, gather some wood, then go sell it to eat and pay alms from the proceeds, than to ask people [for support], which they may grant or refuse."'10

Thus, wara constitutes scrupulous avoidance of all illicit acts, with a special focus on social life (from economic activity, through gossiping, slander and eavesdropping, to cursing or indecency). There is also another important aspect of scrupulosity that should be briefly mentioned here, probably the only one that does not consist of abstaining from doubts or illicit acts. It is the constant examination (literally "accounting") of oneself (Ar. muhāsabat al-nafs), which is an indispensable condition of scrupulosity.

Ibn Mihrān said: "A man does not truly fear God if he does not examine himself scrupulously, meaning his food, drink and clothing - whether they are licit or illicit."

Al-Hasan said: "People whose accounting will be the easiest on the Day of Resurrection are those who examine themselves constantly before God in this world. And the ones whose accounting will be the hardest on the Day of Resurrection are those who took things indiscriminately, with no examination. They shall find God making them accountable for a weight of dust! And they say: 'Woe to us! What kind of a Book is this that leaveth not a small thing nor a great thing but hath counted it!'11 This is a Qurānic verse."12

Even though I attempted to define scrupulosity as the quest for peace and avoidance of doubts, a scrupulous man's heart seems to know no peace as it is in constant fear of transgression. ${ }^{13}$ This constant anxiety is an indispensable condition of scrupulosity, while the scrupulosity is, in turn, indispensable for any religious life. A lack of scrupulosity can even nullify all rituals or religious practices:

\footnotetext{
10 See ibidem, no. 5 , fol. 183 v. This tradition occurs frequently in other compilations.

11 See Sura 18:49 (in Pickthall's translation).

12 See Ibn Ḥabīb, Kitāb al-warac c, no. 69, 70, fol. 185r. Cf. ibidem, no. 5, fol. 18ov.

13 On fear as an integral part of Islamic piety in the period prior to the third/ninth century, see Melchert "Exaggerated Fear."
} 
['Abd al-Malik] said: "Asad b. Mūsā narrated to me from 'Uțmān al-Mawșilī from Yahyā b. Mihrān: 'Īsā b. Maryam (prayers be upon him!) said: Even if you fast until you become thin as straws and if you pray until you become bent like bows, it will not be accepted from you without sincere scrupulosity'”

'Umar b. 'Abd al-'Azīz said: "He who has no scrupulosity and does not abstain from eating forbidden food has no religion at all."14

In his article on fear in the early Islamic pietistic tradition, Christopher Melchert argues that in the second half of the second/eighth century, the "exaggerated fear" disappears from pious practices, being replaced by a more moderate version of piety (and the related theology). Accordingly, the stress of later hadit compilations shifts from presenting heroic models of piety from early Islamic times towards a more accessible paradigm that can be followed much more widely, thereby offering salvation to more people than had previously been the case. ${ }^{15}$

I do not intend to essentially challenge this view. It is true that in the third/ ninth-century pietistic compilations, we no longer see protagonists of Muslim tradition wish they had never been born because of the mere possibility of being condemned to the Fire, or suddenly burst into tears out of such fear. Such imagery all but disappears from pietistic compilations. Yet, even if we find fear replaced by anxiety and constant mindfulness in our sources, the concept of salvation that transpires from the third/ninth-century compilations on warac continues to appear "elitist." There is no hope of salvation for a man unable to avoid doubt in his religion, who fails to constantly keep holding his soul to account. He will not even be saved by dutiful fulfilment of the rituals available and prescribed to every Muslim. While the nature of fear might have changed over time (albeit traditions on Heaven and Hell are far from being uncommon in third/ninth-century pietistic hadit $),{ }^{16}$ in the compilations on scrupulosity, salvation does not seem to be offered to many, still being destined solely for paragons of religion.

Lastly, it should be noted that pietistic compilations do not generally offer theoretical analysis of the discussed concepts. Therefore, it is difficult and challenging to clearly distinguish between zuhd and wara. But for one exception, the compilers provide no definitions of the analyzed concepts, which renders

\footnotetext{
14 See Ibn Ḥabīb, Kitāb al-warac, no. 3, 7, fol. 18ov.

15 See Melchert, "Exaggerated Fear."

16 See, e.g., Melchert, "Locating Hell."
} 
any attempts to distinguish between wara ${ }^{c}$ and zuhd arbitrary. ${ }^{17}$ The only author who does attempt to present religious scrupulosity in a more systematic manner is al-Muhāsibī, who defines its place in a broader mystical system. ${ }^{18}$

What makes Kitāb al-wara' of 'Abd al-Malik b. Habīb stand out among other compilations on religious scrupulosity is its relatively broad interests as well as focus on politics and the relationship of a pious man with political power. Ibn Habīb's Kitāb al-wara contains an extensive chapter on the scrupulous avoidance of friendship with rulers. In fact, a pious man should have no dealings with them at all, as that may cause him to partake in their potentially illicit gains:

Sufyān used to say: "Do not frequent the princes and those who frequent them. Do not eat their food and do not try to imitate them." Then he said: "By God, if it were not reproachable, I would abstain from praying for those who come to the ruler, so that it could become an example."

Sufyān used to say: "Do not yield to the ruler in anything, even if it's the last thing you do. Even if he calls upon you to recite a sūra from the Qurān, do not recite it."19

A ruler and the state in itself, has the power to either condemn a man to the Fire, or aid his salvation:

Al-Awzầi said: "It has reached me that God Almighty destroys subjects, even if they are rightly guided, if their imams are iniquitous. He also has mercy for subjects, be they iniquitous and wicked, if the imams are rightly guided." ${ }^{20}$

17 For a definition of zuhd, see Kinberg, "What Is Meant by Zuhd."

18 See al-Muhāsibī, Kitāb al-makāsib wa-'l-wara', 68. See also Picken, Spiritual Purification in Islam, 74-75. For a comparison of a more "typical" pietistic author, Ibn Hanbal, with al-Muḥāsibī’s approach, see Picken, "Ibn Ḥanbal and al-Muhāāibī.”

19 See Ibn Ḥabīb, Kitāb al-wara, no. 259, fol. 197r; no. 282, fol. 198v. Such a reticence towards the state is a common motive in biographies of many scholars and ascetics. On the political stance of Sufyān al-Tawrī (who appears as the transmitter in both of the quoted traditions and is known to have informally supported the Umayyads), see Judd, Religious Scholars and the Umayyads, 80-90.

20 See Ibn Habīb, Kitāb al-wara', no. 270, fol. 197v. In the next tradition (no. 271, fol. 197v), it is said that the common folk (Ar. al-âmma) are destroyed because of the sins of the elites (Ar. al-hāsșsa), but not the other way around. On al-Awzāīi and his political views, see Judd, Religious Scholars and the Umayyads, 71-79. 
This gives the state a kind of a terrible power over the ultimate fate of believers in the Hereafter. It is only aggravated when political dissent (Ar. fitna) occurs, as it always has eschatological undertones. ${ }^{21}$ In such time, a scrupulous man is expected to maintain his distance from all sides of the conflict and avoid participating in it in any way, even if such quietism would lead to his death:

[The Prophet] (on whom be peace and prayers) said: "A dissent (Ar. fitna) will come, in which a sitting man will be better than a walking one, and a walking man will be better than a riding one." A man asked him: "What are we to do, o Messenger of God?" The Messenger of God (on whom be peace and prayers) was sitting on his mantle - he took its fringe, covered his head with it and said: "Be the killed servant of God."22

Thus, any attempt at participating in the activities of the ruler or the state, not to mention at taking a political stance, can be a threat to scrupulosity and, in consequence, to religion and salvation itself. It is against this backdrop that we should consider the traditions on King David (Ar. Dāwūd) in Kitāb al-wara' of 'Abd al-Malik b. Habīb.

Before proceeding to the analysis of the relevant fragments of this work, I would like to summarize the image of King David in the Quràn and in the oldest known Islamic compilation on David, Hadīt Dāwüd (The Traditions on David) of Wahb b. Munabbih [d. 110/728 or 114/732].

David (Ar. D $\bar{a} w \bar{u} d)$ is described by the Qur'ān as a prophet (Ar. nabì), but not a messenger (Ar. rasūl) of God. As with other biblical characters, the Qurān "assumes" that its readers are generally familiar with the story of David, which is why the Qurānic account is neither chronological, nor particularly detailed.

21 One of the most common meanings of the Arabic term fitna (lit. "refinement of a precious metal") is eschatological tribulation that precedes the end of the world, during which the community of faithful believers is refined like a precious metal to ensure the salvation of the worthy. Cf. Cook, Studies in Muslim Apocalyptic, 20-21, and further bibliography there.

22 See Ibn Habīb, Kitāb al-wara, no. 102, fol. 187r. The compilation contains a separate chapter devoted to the question of what to do during dissent (Ar. Bāb mã yașna'u-'l-muslim fi-'-fitna; no. $106-118$, fol. $187 \mathrm{v}-188 \mathrm{r}$ ), where a similar attitude is recommended. The traditions also provide a list of measures to prevent the spread of dissent (e.g., avoidance of idle talk) and discuss the question of the salvation of its participants. 
Thus, the killing of Goliath (Ar. Ğa $\bar{l} \bar{u} t$ ) is mentioned ${ }^{23}$ and David's image of a military leader is completed by two other passages, ${ }^{24}$ where God teaches him how to make armor for himself and for the protection of his people. It is notable that his military prowess is a result of divine revelation. Elsewhere, it is stated that David received a revelation of the holy book of $Z a b \bar{u} r^{25}$ that can presumably be identified with the Psalms. In addition, he is depicted praising God together with mountains and birds. ${ }^{26}$ There are also some similarities between him and other Islamic prophets; for example, David is the only Qurānic character except Adam to be described as a "viceroy" (Ar. halīfa) of God, ${ }^{27}$ while Sura 5:78 has both David and Jesus curse the unbelieving Jews.

However, the most important Qurānic passage on David is found in Sura 38 (Ar. Sürat Sad), alluding, among other things, to David's affair with Bathsheba. Muhammad is reminded of the story of David and instructed to be patient with the unbelievers casting doubt on God's signs and warnings:

Bear with what they say, and remember our bondman David, lord of might. Lo! He was ever turning in repentance.

Lo! We subdued the hills to hymn the praises with him at nightfall and sunrise,

And the birds assembled; all were turning unto Him.

We made his kingdom strong and gave him wisdom and decisive speech. And hath the story of the litigants come unto thee? How they climbed the wall into the royal chamber,

How they burst in upon David and he was afraid of them. They said: Be not afraid! (We are) two litigants, one of whom hath wronged the other, therefore judge aright between us, be not unjust and show us the fair way.

Lo! This my brother had ninety-nine ewes while I had one ewe and he said: Entrust it to me, and he conquered me in speech.

(David) said: He hath wronged thee in demanding thine ewe in addition to his ewe, and lo! Many partners oppress one another, save such as believe and do good works, and they are few. And David guessed that We had tried him, and he sought forgiveness of his Lord, and he bowed himself and fell down prostrate and repented.

\footnotetext{
23 Sura 2:251.

24 Sura 21:80 and 34:10-11.

25 Sura 17:55 and 21:105.

26 Sura 21:79, 34:10.

27 Sura 38:26 (cf. also Sura 2:30 and 2:251).
} 
So We forgave him that and lo! He had access to our presence and a happy journey's end.

O, David! Lo! We have set thee as a viceroy in the earth, therefore judge aright between mankind and follow not desire that it beguile thee from the way of Allah. Lo! Those who wander from the way of Allah have an awful doom, forasmuch as they forgot the Day of Reckoning. ${ }^{28}$

It is worth noting that the "Bathsheba affair" is never recounted explicitly, but only alluded to in Sura 38:21-24, mentioning the "litigants" (Ar. al-hașm) wanting David to judge between them. This is, of course, a reference to an episode from 2 Samuel, where the prophet Nathan comes to David, tells him the parable of two men, rich and poor, according to which the rich one took the poor one's only lamb. When David says that the rich man should restore the lamb fourfold and die for what he had done, Nathan, comparing David to the wicked rich man, foretells God's vengeance to him for taking Bathsheba and causing the death of her husband, Uriah the Hittite. When David repents, Nathan announces that God has forgiven his sin, but his first child by Bathsheba will die. ${ }^{29}$ It is evident that the Qurannic passage in question is intended for an audience that knew this narrative well. We only find there an outline of the story of David: a potent and wise ruler who is tried by God, succumbs to sin, but is eventually forgiven.

Thus, the image of David in the Qurān can be summarized as that of a prophet enjoying a special relationship with God, receiving revelations and instructions, as well as someone privileged to praise God together with all of nature (Sura 38:18). His piety is eventually tried by God (Ar. fatannā-hu; Sura 38:24) and although David fails this trial he repents and is finally forgiven. It is worth noting that this trial is absent from 2 Samuel, where we simply read that David saw Bathsheba taking a bath, but the whole affair is not described as a test of David's moral integrity. ${ }^{30}$ It can be concluded that David's personal relationship with God, which manifests itself, among other things, in God's will to put David to a trial, seems to set David apart from other Qurānic prophets. It also provides a narrative "framework" that is expanded in the Islamic tradition (including the Qișaș al-anbiy $\bar{a}^{\prime}$ ).

28 Sura 38:17-26, in Pickthall's translation.

$29 \quad 2$ Samuel 12:1-14.

30 2 Samuel 11:2. 
The oldest corpus of hadit dealing with David is Hadit Dāwüd by Wahb b. Munabbih (d. $110 / 728$ or $114 / 732$ ). Wahb was a Yemeni hadit transmitter, probably of Persian origin, who played an important role in the early transmission of Islamic historical traditions. Muslim sources attribute a number of compilations to him, of which only few remnants survive to this day. They can be divided, as suggested by Raif Georges Khoury, ${ }^{31}$ into three principal groups.

The first one includes biblical stories and Judeo-Christian traditions (mainly

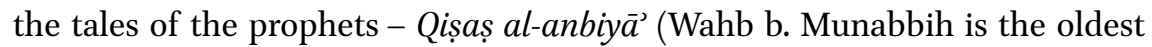
known author of this genre), as well as other compilations of a purely religious nature (e.g., Wahb's most famous work Kitāb al-mubtadä' wa-qișaș al-anbiya ${ }^{\prime}$ [Book of Origin and Tales of the Prophets], ${ }^{32}$ but also Kitāb al-Isrǟilinyyāt [Book of Jewish Traditions], Kitāb zabūr Dāwūd [Book of the Psalms of David], edifying and pietistic compilations like Hikmat Luqmān or Maw izat Wahb [The Wisdom of Luqmān or Exhortation of Wahb], as well as Tafsir Wahb). It is also possible that Wahb, who at some point in his life allegedly adopted the doctrine of qadar, wrote Kitāb al-qadar (Book of Divine Decree). The second group are compilations on Islamic history, Futūh Wahb (Wahb's History of Conquests) and Maġāzi rasūl Allāh (Raids of the Messenger of God). Finally, the third group of Wahb's works concerns pre-Islamic Arabia and contains only one compilation, Kitāb al-mulūk al-mutawwağa min Ḥimyar wa-ahbāri-him wa-qișași-him wa-qubūri-him wa-ašāri-him (Book of the Crowned Kings of Himyar: Their History, Tales, Tombs and Poems).

The main difficulty that arises when one tries to assess Wahb's literary production is the fact that most of these works are known to us only by their titles or from passages quoted in later works. We cannot even be certain of the exact titles of some of Wahb's works or their number. This state of preservation is not surprising, given the fact that Wahb b. Munabbih was an early transmitter and very few texts survived from his time (i.e. the turning point of the first/seventh and the second/eighth century). It is also worth noting that, at this early stage of development of the Islamic tradition, the very notion of authorship was not what it is today - a compilation "by" Wahb b. Munabbih did not mean a collection whose form and content had necessarily been determined by Wahb

31 On Wahb b. Munabbih's life and work, see Khoury, Wahb b. Munabbih, vol. 1, 189-316 and further bibliography there. My enumeration of Wahb's compilations is based on this work. I am deeply grateful to Dr. Maciej Klimiuk of the University of Heidelberg for providing me with a copy of this text.

For other possible versions of this title, see Khoury, Wahb b. Munabbih, vol. 1, 222-23. 
himself. Rather, it refers to a collection of traditions transmitted orally by Wahb and only at a later date put into writing. The form of such compilations could have depended on many factors such as the needs of intended readership or audience, ways of transmission, or the nature of human memory. Accordingly, the books mentioned by Wahb's biographers could have been later collections put together on the basis of oral transmission. Thus, while it is possible to have some general idea of the content of these collections, it is impossible to reconstruct their original form. In many cases, it is also very difficult to determine the sources of Wahb's traditions. For example, hadit constituting Islamic versions of biblical narratives was quite prevalent in his transmission. It is, however, impossible to ascertain whether Wahb was a converted Jew or Christian, or whether he had taken his stories on prophets from other sources.

The only two extensive and independent (i.e., not contained in other compilations) fragments of Wahb's works are preserved in a papyrus held in the library of the University of Heidelberg, bearing the signature PSR Heid. Arab. 23. This papyrus, containing a work entitled Hadīt Dāwüd (Traditions on David), as well as fragments of Majāzzì rasūl Alläh (Raids of the Messenger of God), was published and translated into German by Raif Georges Khoury. ${ }^{33}$

Maḡàzi rasūl Allāh will not concern us here, as it is a compilation on early Islamic history, but Hadīt Dāwūd is of utmost interest to the present article, as it is a very early source on the Islamic David. Moreover, Wahb b. Munabbih appears in many (relatively speaking) of the isnāds of traditions transmitted by 'Abd al-Malik b. Habīb throughout his compilations (though, as we will see, the links between Hadīt Dāwūd and Kitāb al-wara' are rather limited). There is a possible connection between Wahb's transmission and the relatively important role played by David in Ibn Habīb's Book of Religious Scrupulosity and therefore a brief discussion of the Hadīt Dāwūd is in order.

First of all, the relationship between Hadit $\underline{D} \bar{a} w \bar{u} d$ and other compilations attributed to Wahb concerning prophetic history, Kitāb al-mubtadä’ wa-qișaș $a l$-anbiy $\bar{a}^{\prime}$ and the Kitāb al-Isräalliyya $\bar{a}$, remains unclear. It is probable that Hadīt Dāwüd was a part of one of these works, however, it cannot be ruled out that it formed a separate compilation, unmentioned by Wahb's biographers. As noted above, David could have played an important role in Wahb b. Munabbih's transmission, since another, now lost, work, bearing the title of $Z \bar{a} b \bar{u} r D \bar{a} w \bar{u} d$ (presumably a version of the Psalms) is attributed to this author. It is, of course, impossible to assess its relationship to Hadīt Dāwi $\bar{u}$ from the Heidelberg papyrus alone.

33 See ibidem, vol. 1, 33-115 (Hadìt Dāwūd) and 117-175 (Maj̇āzì rasūl Allāh). The second volume of this work contains a facsimile of the papyrus. 
Generally speaking, Hadīt Dāwūd is a compilation of chronologically arranged traditions recounting the biblical narrative of 1 and 2 Samuel, spanning the time from the reign of Saul (Ar. Țälüt) until that of Solomon (Ar. Sulaymān). Little wonder, therefore, that David is the central character of this compilation. Although its detailed analysis is beyond the scope of the present paper, several things should be noted. First of all, the traditions on David greatly expand what is only alluded to in the Qur'ān. For example, we have seen that, in the Qurān, David is taught by God how to defend himself and his people. In Hadīt Dāwūd, we find a tradition according to which David was collecting stones for his sling (with which he was later to kill Goliath/Ğàlüt) and three of these stones spoke to him, urging him to take them. It turned out that one of them had previously belonged to Abraham (Ar. Ibrāhìm), another one to Isaac (Ar. Ishāa), the third one to Jacob (Ar. Yáqüb), and that these patriarchs had killed many foes with them. ${ }^{34}$ This example encompasses the aforementioned important aspects of the Quranic image of David, most notably his special, personal relationship with God, as well as what links him to other prophets and the history of Israel.

In accord with Islamic tradition on David, one of the most important episodes in his life reported by Hadīt Dāwūd is his sin, which resulted in sending Uriah to his death and the taking of his wife, Bathsheba. A curious trait in this compilation is that David believed that a sinless life is possible for a man and actually wished to be tried by God, just like other prophets had been tried before him:

David said: "O, Lord! You have put to trial those who lived before me and you have exalted them in posterity by virtue of their endurance, but you have not put me to trial!" God revealed to him: "O, David (Ar. $D \bar{a} w \bar{u} d)$ ! You have chosen trial over salvation (Ar. Inna-ka (i)htarta-'l-bala 'alā-'l-'áfiya $),{ }^{35}$ so take heed, for I shall put you to trial within this month of yours." It was a Monday afternoon, the thirteenth day of the month of rağab. ${ }^{36}$

A striking element in this narrative is a certain hubris exhibited by David, who actually invites a trial from God, being convinced that he is capable of living

34 See Wahb b. Munabbih, Hadīt Dāwūd, 7, v. 9-16, in Khoury, Wahb b. Munabbih, vol. 1, 52-53. See also 12, v. 13-18, 66-67 (henceforth Hadīt Dāwūd), where David is described as making armors and selling them in order to gain sustenance and give alms to the poor. Ar. 'Áfiya is a specific term that can mean safety from a trial or danger brought upon by God.

$3^{6}$ See Hadīt Dāwüd, 14, v. 13-17. Cf. Khoury, Wahb b. Munabbih, vol. 1, 70-71. The translation is mine. 
without succumbing to $\sin .^{37}$ But this hubris also results from a desire to be equal to other prophets who lived before him. Thus, it is yet another strategy employed by the Muslim tradition to create a link between David and other biblical prophets and, in a broader sense, between Islam and other Abrahamic religions. David fails the test (unlike the prophets before him, "exalted in posterity by virtue of their endurance"), but his penance and subsequent forgiveness is one of the crucial traits of his image in Muslim tradition. ${ }^{38}$ The compilation describes the life of penance that David leads after his sin, and ends during the reign of his son, Solomon.

In general, Wahb b. Munabbih's Hadīt Dāwūd, whether it originally consti-

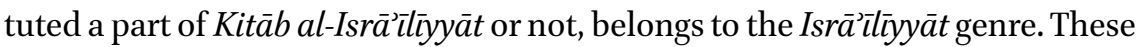
traditions contain narratives loosely related to biblical accounts and served to "bridge the gap" between Islam and other Abrahamic religions, often expanding and/or interpreting the text of the Qurān. Accordingly, Hadīt Dāwūd shows the formation of the Islamic image of David at a very early stage. The main focus seems to be that of depicting David in relationship to earlier prophets, inscribing him into a broader Islamic history of salvation. This aspect would later change, becoming less prevalent in later texts such as Kitāb al-wara' of 'Abd al-Malik b. Ḥabīb. ${ }^{39}$

\section{$5 \quad$ King David in Kitāb al-warac}

A distinctive feature of Ibn Ḥabīb's Book of Religious Scrupulosity in comparison to other similar compilations is the presence of a series of nine traditions ${ }^{40}$ dedicated to King David and contained in one of the last chapters of the book, dealing with the merits of old age. ${ }^{41}$ Although Kitāb al-wara' contains traditions featuring prophets other than Muhammad, no other prophet save for David (Ar. Dāwūd) appears in a series of hadīt that can be considered a set

37 See ibidem, 14, v. 1-3, 69-71.

38 For a thorough account of this episode in the Islamic tradition, see Mohammed, David in the Islamic Tradition.

39 For more on David in the qișaș al-anbiy $\bar{a}^{\prime}$ genre, see Klar, Interpreting al-Tha lab’’s Tales of the Prophets, 95-141.

40 See Ibn Habīb, Kitāb al-wara, no. 317-325, fols. 20ov-201r.

41 It should be noted that traditions on Adam's repentance (no. 315, 316, fol. 20ov) and David are digressions from the main subject of the chapter, which is old age and God's increased leniency towards those who reached it. One can wonder whether the organization of materials included in the book is not corrupted in this unique preserved manuscript (at least in this chapter). 
constituting a coherent story. The last of these traditions ends with a telling phrase: "This is the story of David (on whom be peace and prayers)."42

All nine traditions revolve around the "error," or "sin" (Ar. hatiia) of David (Ar. $D \bar{a} w \bar{u} d)$. It might be interesting to note that the nature of this sin is never explicitly specified in these traditions. Presumably, the episode was famous enough and therefore such a clarification was unnecessary. The nine traditions are brief enough to be quoted here in extenso:

It is narrated from Abū Ṣāliḥ, from Ibn 'Abbās who said: "When Dāwūd committed his error, he called upon his servant named Šim'ūn, stripped himself of his kingly garments and donned a garment of wool, with a rope around his waist. He said to the servant: 'Lead me as a sinner who is led to a place of punishment.' So, he led him to a mihrāb, where Dāwūd was prostrating fervently before God."

Al-Ḥasan said: "[Dāwūd] was prostrating for the best part of the night, until it was called to him: 'Raise your head, for you have been forgiven,' so he raised his head and saw a prayer carpet made of flesh (Ar. siğğäda $\min (a h m)^{43}$ (?)."

Wahb b. Munabbih said: "He did not raise his head until the angel said to him: 'First you sin, and you rebel at last! Raise your head!' And he raised it."

Sulaymān al-Ta'ī said: "Dāwūd was prostrating until his forehead and knees were wounded and herbs grew from his tears and he prayed: '[O, God! ] If you wanted, you would deliver me from error.' God had mercy on him and forgave him and he did not raise his eyes to heaven, because of his shame before his Lord, until he died."

Wahb b. Munabbih said: "Dāwūd lived very long and did not drink water without mixing it with his tears and did not break his fast on his bed without making it wet from his tears, to the point where the drapes did not dry."

Abū Darr said: "When God forgave Dāwūd, he used to dedicate one day to governing, one day to his women and one day to his weeping."

Taabit said: "When Dāwūd used to mention God's punishment, all the members of his body trembled as if they had become dislocated."

Sulaymān said: "After what happened, Dāwūd did not sleep with a woman and kept abstaining from it until he departed from this world."

Ar. fa-hā no. 325 , fol. 2 oir.

The last detail is difficult to interpret. 
Al-Ḥasan said: "In fits of anguish Dāwūd remembered his error and exited [his palace] screaming, going to the Temple (Ar. bayt al-maqdis). The sons of Israel left their tents for him and he said to them: 'Fend for yourselves! I want to mourn! Verily, the one who commits an error weeps over it!' This is the story of Dāwūd (on whom be peace and prayers)."

Surprisingly, despite the fact that Wahb b. Munabbih is quoted twice in the isnāds, the traditions of Ibn Habīb are not included in the Hadìt Dāwud from the Heidelberg papyrus. In this compilation, we do not find the narrative about the angel scolding David for refusing to raise his head after being forgiven. We only read that God announced to David His forgiveness, but David did not raise his head "until Gabriel came." ${ }^{4}$ What follows is a rather long account (absent in Kitāb al-wara ${ }^{\text {) }}$, in which God convinces David of His forgiveness by making him go to the tomb of Uriah and call upon him. David converses with the dead Uriah, confessing his sin and the way in which he has wronged him. In the end, God reveals to David how He would reward and compensate Uriah in the Hereafter, and it is only at that moment that David believes that he is forgiven. ${ }^{45}$ Thus, if we compare Hadīt $D \bar{a} w \bar{u} d$ with Ibn Habīb's version, the latter appears much more truncated. Moreover, the tradition from Kitāb al-wara' introduces a detail absent from Wahb b. Munabbih, namely David being scolded by the angel for refusing to raise his head.

The second instance where Wahb b. Munabbih appears is the tradition depicting David weeping after having sinned. Unfortunately, the only tradition in Hadīt Dāwūd that could be perceived as a possible source for Ibn Habīb appears at a place where the papyrus is highly deteriorated and it was impossible for Khoury to read or reconstruct the whole text. ${ }^{46}$ Moreover, the context (i.e., the surrounding traditions) does not make such a possibility very probable, so I think it is safe to conclude that this tradition does not appear in Hadīt Dāwūd.

Only one tradition transmitted by Ibn Ḥabīb has a counterpart in Hadit $D \bar{a} w \bar{u} d$, though the latter version is much longer. In addition, Ibn Ḥabīb quotes

\footnotetext{
44 See Wahb b. Munabbih, Hadīt Dāwūd, 18, v. 12-13, Cf. Khoury, Wahb b. Munabbih, vol. 1, $80-81$.

45 See ibidem, 18, v. 14-20, v. 16, vol 1, 80-85.

46 See Wahb b. Munabbih, Hadịt Dāwūd, 19, v. 20 in Khoury, Wahb b. Munabbih, vol. 1, 84-85, cf. Ibn Habīb, Kitāb al-wara', no. 321, fols. 20ov-201r. A form of the šrb root appears in the preserved text of Hadīt Dāwi $\bar{u}$, so it is possible that the tradition speaks of David mixing his drinking water with his tears, but there is no other, more convincing, argument for that. On the drapes of David, wet from tears, cf. Wahb b. Munabbih, Hadīt Dāwūd, 2o, v. 19-20.
} 
Abū Darr and not Wahb b. Munabbih as its source in Kitāb al-wara ${ }^{4}{ }^{77}$ It is therefore possible to conclude that despite the fact that Wahb is mentioned twice in Ibn Habīb's series on David quoted above, Hadīt Dawūd and Kitāb al-wara have little in common. Furthermore, there is no evidence that Ibn Habīb used any compilation by Wahb b. Munabbih. Hadit was largely transmitted orally (especially at the time of Wahb), Ibn Habiib was notorious for truncating his isnäds (which often renders impossible the task of tracing the sources of his traditions) and, as we have seen, we are uncertain of the status of Hadit $\underline{D} \bar{a} w \bar{u} d$ (was it a fragment of a larger compilation or a separate work?) and its circulation. All these problems greatly complicate the task of establishing firm connections between the compilations of Wahb and those of Ibn Habīb.

The closest counterpart of this series of traditions in the pietistic literature of the third/ninth century is the chapter on David's piety (Ar. zuhd) in Ibn Hanbal's Kitāb al-zuhd ${ }^{48}$ However, although the repentance of Dāwūd after the "Bathsheba affair" remains an important theme also in this compilation, it is hardly the only subject present in this chapter; it also deals with the manner in which the prophet prayed (with no apparent relation to Bathsheba) and remembered God, how he feared Him and His punishment, or with the book of Zabür. On the whole, the image of David in Ibn Hanbal's compilation seems fundamentally different from the one contained in Ibn Habīb's Kitāb al-warac . Ibn Hanbal's David appears closer to a general ideal of piety, manifesting itself not only in repentance, but also in prayer, remembrance of God (Ar. dikr Alläh) and fear of His punishment. Such a representation of David is generally coherent with the nature of Ibn Hanbal's Kitāb al-zuhd - a peculiar work, if one compares it to other pietistic compilations of the period, because it is a collection of hadit dealing with examples of the piety of the prophets. Apparently, Ibn Hanbal aims to prove thereby that the model of zuhd advocated by him and his contemporaries can be traced back to the times of the prophets and thus legitimate. The question that arises is why Ibn Habib's David is so distant from this paradigm. He is the only prophet to be presented in a series of traditions, but the narratives revolve only around his repentance and penance for his sin.

\footnotetext{
47 According to this tradition, David dedicated one in three days to ruling, one to his women and one to weeping. Wahb's version is longer and speaks of four days. See ibidem, 20, v. $1-22$.

See Ibn Ḥanbal, Kitāb al-zuhd, 135-141.
} 
The Qurān, Hadīt Dāwūd of Wahb b. Munabbih and Kitāb al-wara' of 'Abd al-Malik b. Habīb each seem to witness a different stage in the complex process of the formation of the image of David/Dāw $\bar{u} d$ in classical Islam. The Qurānic fragments, with their allusive style, are evidently intended for an audience (or readership) familiar with the biblical story of David. They introduce him as one of the prophets in the historia sacra, which starts with the creation of Adam and concludes with the mission of Muhammad. The crucial aspects (further developed in later Muslim sources) of the Qurānic character of David are his special relationship with God, his ties with other prophets (from the past as well as the future, like Jesus/ $\bar{T} s \bar{a}$ ), and his sin and repentance. David's special relationship with God manifests itself in the fact that God teaches him how to make armor for himself (the killing of Goliath/Ğâtūt is mentioned as well). In addition, David is depicted as someone capable of praising God like no other prophet before or after him; all of creation joins him in this praise.

The relationship with other prophets serves the purpose of inscribing Islam (or, more specifically, the mission of Muhammad) into the history of salvation, encompassing other Abrahamic religions, and by doing so to "legitimize" it in the eyes of Jews and Christians. Hadit Dāwūd by Wahb b. Munabbih belongs to the Isräatliyyät genre, i.e. traditions supposedly taken from the Jews, containing Islamic versions or interpretations of biblical narratives. As such, they were used primarily to create a link between Islam and the "biblical past" and it is at this point of transmission of Wahb b. Munabbih's hadit (the second/eighth century) that we see that the story of David is enriched with a considerable number of details - the Isräìliyyāt would later become a basis for the qișaș al-anbiy $\bar{a}^{3}$ narratives on prophets (a compilation of one such title is already attributed to Wahb b. Munabbih).

The case of 'Abd al-Malik b. Habīb and his Kitāb al-wara' is different. In mid-third/ninth century, a peculiar type of piety emerges, largely focused on religious scrupulosity (Ar. wara) and renunciation (Ar. zuhd), as well as pervaded with apocalyptic anguish. Another of its distinctive features was, sometimes very sharp, rejection of the state and its institutions, perhaps best visible in Kitāb al-wara' by 'Abd al-Malik b. Habīb. This paradigm of piety is expressed throughout a number of compilations of hadit tassembled during this period, while a relatively high number of traditions on David/Dāwüd is a peculiar feature of the Kitāb al-wara.

The theme that is best visible in all these traditions is David's excessive repentance, manifesting itself in weeping (in two traditions), ${ }^{49}$ shame result-

See Ibn Habīb, Kitāb al-warac, no. 321, 322, fols. 20ov-201r. 
ing in refusal to raise his head from prostration ${ }^{50}$ and look up to the heavens, or refraining from sexual intercourse. ${ }^{51}$ However, given the aforementioned focus of Ibn Habib on political matters and on dangers that the state or the ruler constitute for a pious man, in my view, the most important image in this series of traditions on David may be the stripping of his kingly garments ${ }^{52}$ and exiting his palace in "fits of anguish" upon remembering his sin. ${ }^{33}$ If the state and power are indeed such a nefarious and destructive force threatening to condemn every faithful man, then it is hardly surprising that David, in order to regain the grace of God, has to resign his royal dignity and power. Thus, the answer to our question regarding the relative importance of David in Ibn Habib's compilation implies that it is connected with the importance of political (and eschatological) themes in Kitāb al-wara .

\section{Bibliography}

\section{Primary Sources}

Asad b. Mūsā. Kitāb al-zuhd. Edited by Raif Georges Khoury. Wiesbaden: Harrasowitz Verlag, 1976.

Ibn Abī al-Dunyā. Kitāb al-wara'. Edited by Abū 'Abd Allāh Muhammad b. Aḥmad al-Ḥammūd. Kuwait: no publishing house, 1988.

Ibn Ḥabīb. Ašrāt al-sāa wa-dihāab al-ahyār wa-baqă’ al-ašrār. Edited by 'Abd Allāh 'Abd al-Mu’min al-Ġamārī al-Hasanī. Riyād: Dār aḍwā’ al-salaf, 2005.

Ibn Ḥabīb. Kitāb adab al-nisā’ al-mawsūm bi-Kitāb al-ġāya wa-'-nihāya. Edited by 'Abd al-Mağīd Turkī. Beirut: Dār al-g̉arb al-islāmīī, 1987.

Ibn Habīb. Kitāb al-ribā. Edited by Nadīir Awhāb. Dubai: Markaz Ğumu'at al-Mağīd li-'l-țaqāfa wa-'l-turāt, 2012. Spanish translation: Adday Hernández López. El Kitāb al-ribā de 'Abd al-Malik b. Habīb (m. 238/852). Doctrina temprana legal sobre la usura. Madrid: Consejo Superior de Investigaciones Científicas, 2017.

Ibn Habīib. Kitāa al-ta'rīh. Edited by Jorge Aguadé. Madrid: Consejo Superior de Investigaciones Científicas, 1991.

Ibn Hạaīb. Kitāb al-wādiha: Das 'K. al-wādiha' des 'Abd al-Malik b. Habīb: Edizion und Kommentär zu Ms. Qarawiyyin 8og/40, edited by Beatrix Ossendorf-Conrad. Stuttgart: Steiner Verlag, 1994 and (other fragments of the same work) Kitäb

50 According to one of the traditions, he is scolded by the angel for refusing to raise his head. See ibidem, no. 319, fol. $200 v$.

51 See ibidem, no. 324, fol. 201r. Cf. also no. 322 (fol. 201r.), where David dedicates every one in three days to his women.

$5^{2}$ See ibidem, no 317 , fol. $200 v$.

53 See ibidem, no. 325, fol $201 r$. 
al-wādiha (Tratado jurídico. Fragmentos extraídos del "Muntajab al-ahkām" de Ibn Abī Zamanīn (m. 399/10o8)). Edited by María Arcas Campoy. Madrid: Consejo Superior de Investigaciones Científicas, 2002.

Ibn Ḥabīb. Kitāb waşf al-firdaws, no name of the editor. Beirut: Dār al-kutub al-islāmī, 1987. Spanish translation: Kitāb wasf al-firdaws (la descripción del paraíso), trans. Juan Pedro Monferrer-Sala, Granada: Grupo de Investigación "Ciudades Andaluzas bajo el Islam," 1997 .

Ibn Ḥabīb. Muhtașar fi-l-țibb (Compendio de medicina). Edited by Camilo Álvarez de Morales and Fernando Girón Irueste. Madrid: Consejo Superior de Investigaciones Científicas, 1992.

Ibn Hanbal. Kitāb al-wara . Edited by Zaynab Ibrāhīm Qārūt. Beirut: Dār al-kutub al-ilmiyya, 1987 .

Ibn Ḥanbal. Kitāb al-zuhd. Edited by Muḥammad Ğalāl Šarf. Beirut: Dār al-nahḍa al-'arabiyya, 1981.

al-Muhāsibī. Kitāb al-makāsib wa-'l-wara', edited by 'Abd al-Qādir Aḥmad 'Ațā. Beirut: Mu’assasat al-kutub, 1987.

\section{Secondary Literature}

Arcas Campoy, María. "La autoridad doctrinal de 'Abd al-Malik ibn Ḥabīb (m. 238/835) frente a los cadíes y alfaquíes de su tiempo." In Cadíes y cadiazgo en al-Andalus y el Magreb medieval, edited by Rachid El Hour and Rafael Mayor, 47-67. Madrid: Consejo Superior de Investigaciones Científicas, 2012.

Arcas Campoy, María, Serrano Niza, Dolores. "Ibn Ḥabīb." In Biblioteca de al-Andalus, edited by Jorge Lirola Delgado and José Miguel Puerta Vilchez, 9 vols., vol. 3, 219227. Almería: Fundación Ibn Tufayl de Estudios Árabes, 2004-2012.

Cook, David. Studies in Muslim Apocalyptic. Princeton: The Darwin Press, 2001.

Fierro, Maribel. La heterodoxia en al-Andalus durante el periodo omeya. Madrid: Instituto Hispano-Árabe de Cultura, 1987.

Fierro, Maribel. "Proto-Malikis, Malikis and Reformed Malikis in al-Andalus." In Islamic School of Law. Evolution, Devolution and Progress, edited by Peri Bearman, Rudolph Peters and Frank E. Vogel, 57-76. Cambridge, MA: Harvard University Press, 2005.

Hurvitz, Nimrod. "Biographies and Mild Asceticism: A Study of Islamic Moral Imagination." Studia Islamica, 85 (1997), 41-65.

Judd, Steven. Religious Scholars and the Umayyads. Piety-minded Supporters of the Marwānid Caliphate. London - New York: Routledge, 2014.

Khoury, Raif Georges. Wahb b. Munabbih, 2 vols. Wiesbaden: Harrasowitz Verlag, 1972. Kinberg, Leah. "What Is Meant by Zuhd." Studia Islamica, 61 (1985), 27-44.

Klar, Marianna O. Interpreting al-Tha labı̈s Tales of the Prophets. Temptation, Responsibility and Loss. London - New York: Routledge, 2009. 
Melchert, Christopher. "The Piety of the Hadith Folk." International Journal of Middle East Studies, 3(34) (2002), 425-439.

Melchert, Christopher. "Exaggerated Fear in the Early Islamic Renunciant Tradition." Journal of the Royal Asiatic Society, 3(21) (2011), 283-30o.

Melchert, Christopher. "Locating Hell in Early Renunciant Literature." In Locating Hell in Islamic Traditions, edited by Christian Lange, 101-123. Leiden: Brill, 2015.

Mohammed, Khaleel. David in the Islamic Tradition. The Bathsheba Affair. Lanham Boulder - New York - London: Lexington Books, 2015.

Picken, Gavin. "Ibn Hanbal and al-Muhāsibī: A Study of Conflicting Scholarly Methodologies." Arabica, 3-4(55) (2008), 337-361.

Picken, Gavin. Spiritual Purification in Islam. The Life and Works of al-Muhāsibī. London - New York: Routledge, 2011.

Pitschke, Christoph. Skrupulöse Frömmigkeit im Frühen Islam. Das "Buch des Gewissensfrömmigkeit” (Kitāb al-wara) von Ahmad b. Hanbal. Wiesbaden: Harrasowitz Verlag, 2010. 